\title{
The Role of Human Capital in the Economic Development and Social Welfare in Albania
}

\author{
Arjola Mitaj \\ University “Eqrem Cabej”of Gjirokastra, Albania \\ Email: a_mitaj@yahoo.com \\ Klodian Muco (Corresponding Author) \\ University “Eqrem Cabej”of Gjirokastra, Albania \\ Email: klodianmuco@hotmail.com \\ Jonida Avdulaj \\ Albania University “Eqrem Cabej”of Gjirokastra, Albania \\ Email: jonidaqendro@hotmail.com
}

Received: January 19, 2016 Accepted: February 07, 2016 Published: February 28, 2016

doi:10.5296/ijhrs.v6i1.9059 URL: http://dx.doi.org/10.5296/ijhrs.v6i1.9059

\begin{abstract}
Continuously, the relation between education and economic development has been the focus of development researchers' studies that study long-term growth. While theoretical models recognize education as the key to a country's economic growth (Bassanini and Scarpetta, 2001; Fuente and Ciccone, 2003; Jones, 2005 Bassanini, 2007), the importance of education is very low in empirical models.

The reason for this discrepancy is that for a long time education is measured by the years attended in school and not by the knowledge and skills gained, which according to an OSCE study, a student competences growth of 100 points (measuring unit) produces an increase of $2 \%$ of GDP per capita. Thanks to this identification, education is recognized as one of the main keys to development.

Various empirical studies show that productivity can be increased through training (Barrett and O'Connell, 2001; Scrutinio et al., 2006). In sum, these studies show that pre university, university education and training courses positively affect the increase of production, which
\end{abstract}


in turn can positively affect the economic development of a country.

Thus, this article tends to evaluate the role of Albanian human capital in economic development of the country considering the relationship between education and productivity.

Keywords: Human capital, Economic development, Productivity, Education, Albania

\section{The Importance of Human Development. Evidences from Relevant Literature}

For a country like Albania, which has traversed a long transition period with multiple efforts to suit the market economy and paces of the countries that already belong to the EU, education remains an essential element. In these conditions the reforms of the education system are also vital to the wider process of societal change that both underpin economic reform and which is needed in its own right. Education and policies that a country pursues in accordance with cannot be seen as separated from reforms in other areas of the economy. The connection is clear considering the fact that long-term success of these reforms depends largely on the ability of the human capital of a country to absorb and to exercise the knowledge that is necessary to compete internationally. For this purpose, $n$ the UNDP report on Human Development, the definition of the latter includes a number of aspects: Human development is about equal life chances for all. It involves not only expanding capabilities to broaden people's present choices - to live healthy, productive and safe lives-but also ensuring that these choices do not compromise or restrict those available to future generations (HDR, 2014, pg.33).

According to this report, Albania is ranked the $95^{\text {th }}$ country in the world with a HDI of 0.716 in 2013, participating to the list of countries with high human development. While other countries of the region are positioned higher than Albania, Serbia-0.745, Montenegro-0.789, Macedonia-0.732, Bosnia and Herzegovina-0.731 respectively (OECD, 1998). Different studies, both theoretical and empirical have tried to explain the differences between countries regarding their rates of economic growth under the influence of human capital. Hanushek and Kimko (2000) address the problems of the differences in the quality of labor force and prove that they have a high effect in growth rates of countries. They conclude that labor-force quality differences are important for growth; that these quality differences are related to schooling and that quality has a causal impact on growth (Hanushek and Kimko, 2000). Why so much attention paid to human capital and its impact on economic growth of a country? There are multiple connections which are not always direct, but new growth models link the competitiveness of the economy to its ability to generate innovations and Improve Productivity through human capital. Schumpeter (1954) considers innovation a sub-product of education and a very important for the economic growth of a country. This innovation, according to him can be attained by allocating to young entrepreneurs an important role particularly because of their ability to innovate. Chen and Dahlman (2004), point out that the stock of human capital, associated with appropriate knowledge acquired through relevant education and the level of domestic innovation and technological adaptation, are those that lead a country to development. Specifically: "A well-educated and skilled population is 
essential to the efficient creation, acquisition, dissemination and utilization of relevant knowledge, which tends to increase total factor productivity and hence economic growth", . Their study about incremental effects of human capital proved that an increase by 20 percent in the average years of schooling of a population tends to increase the average annual economic growth by 0.15 percentage point (World Bank, 2004, pg.44).

Hanushek (2002) emphasizes that a more educated society, may lead to higher rates of invention; may make everybody more productive through the ability of firms to introduce new and better production methods; and may lead to more rapid introduction of new technologies.

Barro (1992) highlights another way how human capital can affect or accelerates economic growth and this is through the fertility rate. He explains that a higher stock of human capital motivates families to choose a lower fertility rate and to raise the investment in human capital for each child (that is, to substitute quality for quantity in children). These responses of population growth and human capital investment tend to raise the growth rate of output (Barro, 1998).

Investing in the human capital of a country brings benefits not only in individual aspect, given that higher levels of education or schooling directly are correlated with higher levels of reward and standards of living (Haveman et al., 1998). Because of this, government expenditures corresponding to education in general occupy a certain percentage of the state budget. In certain countries, especially developing ones, the fact that the share of public expenditure for education real may decline, especially for long periods of time, is translated into lower incomes for households. This in turn, reduces the available resources of the family members to educate their children- not only in terms of tuition payment but also in the term that what is called "preparedness" of children for school in terms of health, nutrition, and mental development.

Education from the other part has a strong impact on the probability of an individual to be a member of a group. Thus, expanding education opportunities would apparently increase the incentive to participate in groups and enhance the stock of social capital. The investment in human capital has to do not only with the primary level of education or even the three level of education. According to Mincer (1981), it is not merely training on the job (formal or informal), but also the processes of occupational choice that give rise to investments beyond schooling. Similarly, geographic mobility and other labor turnover in search of higher real earnings represent investments in human capital.

The term competitiveness is often cited as a prerequisite for Albania to experience a rapid and stable growth. Higher competitiveness regarding the quality of products and services, in the diversification of export's basket that would support on the other hand higher rates of exports growth; competitiveness in the form of systemic competitiveness, based on the principle of public-private partnership (ITC, 2003, pg.4). But what should not be forgotten is the fact that a country can create a competitive advantage through the accumulation of human

\footnotetext{
${ }^{1}$ World Bank Policy Research Working Paper 3366, August 2004, pg. 8.
} 
capital. Specifically for the entire society it is important the ability of its human capital to increase its productivity faster than its costs. In this context, it is worth emphasizing the crucial importance of education as the key element of investment for the improvement of human capital (Fullani, 2012). On the other hand the development and accumulation of capital, together with a well-educated human labor force would help generate new innovative ideas which will be finalized in the products and services provided by a country.

Referring to the Global Competitiveness Index, Albania ranks $104^{\text {th }}$ in regards to business sophistication and $120^{\text {th }}$ (out of 144 countries) regarding innovation. While other countries of the region rank much better than Albania considering these two indexes (FYR Macedonia $89^{\text {th }}$ and $68^{\text {th }}$ respectively; Montenegro $97^{\text {th }}$ and $58^{\text {th }}$ ). Important significance shows the index of Higher Education and Training where Albania ranks $60^{\text {th }}$ out of 144 countries. (Macedonia $71^{\text {th }} ;$ Montenegro $\left.51^{\text {th }}\right)^{2}$

However the literature is rich of studies proving that the education or training as forms of investment on human capital also have indirect effects, some of them are uneconomic. These externalities are associated with improvements to the environment, better health and reduced crime rates or demonstrate how geographical clustering of businesses employing highly qualified workers produces high productivity and strong local economic growth. Other significant spillovers relate to health and life expectancy, which typically increases as a consequence of higher levels of education (OECD,1998, pg.52).

In connection to the question if it is the development of human capital the one that affects and leads to higher economic growth or the other way around, again there is evidence which conclude in different ways. A study of recent years is that of Mehrara and Moses (2013) that takes into consideration 101 developing countries over the period 1970-2010 and uses the Granger test to examine the causality between human capital and income. The findings of this paper support the point of view that it is higher economic growth that leads to higher human capital. The results suggest that there is strong causality running from GDP and investment to human capital with no feedback effects from human capital to GDP for developing countries. What was more important in this study and worth mentioning here consists on the inverse relationship (negative) between the number of students involved in education and the quality of education. This may be the reason why huge educational investments in these developing countries fail to generate higher growth (Mehrara and Musai, 2013).

Finally Mincer (1981) considers human capital as related to physical capital. According him the contribution of physical capital is larger the higher the average level of human capital. But, while physical plant and equipment can be acquired or built quite rapidly, the development of a significant and broadly based level of human capital of a nation is a lengthy process which involves profound social and cultural changes (Mincer, 1981, pg.17).

\footnotetext{
${ }^{2}$ Global Competitiveness Report, 2014-2015.
} 
2. The Empirical Analysis Of The Impact That Human Capital Might Have On Economic Development In Albania

Given the evidence mentioned above, the paper continues with an empirical study of the impact of human capital in the economic development of the country. As variables that measure the stock of human capital will be used: public spending on youth education, gross enrollment ratio and youth literacy rate. It will be considered their impact on productivity growth, which is a key indicator of the growth of competitiveness and has a high and positive impact on a country's GDP. The second and third explanatory variables are those that are widely used as a proxy of human capital. It is also valuable the inclusion of costs that correspond to education based on the arguments mentioned above.

To achieve the analysis our work begins with the construction of a linear and multivariable model, taking as dependent variable the productivity and as independent ones Education_Expen (Ee), Gross_enrolment (Ge) and Youth_Literacy (Yl). So the following equation can be written: Productivity $=\beta_{1}+\beta_{2} E e+\beta_{3} G e+\beta_{4} Y l$. Using the Gretl program to process the data, we get the following results:

Table 1, Model 1, OLS, using observations 2003-2014 ( $T=12)$ Dependent variable: Productivity

\begin{tabular}{lccccc}
\hline & Coefficient & Std. Error & t-ratio & p-value & \\
\hline \multicolumn{1}{c}{ const } & 505851 & 274512 & 1,8427 & 0,10261 & \\
Education_Expen & $2,03837 \mathrm{e}-05$ & $6,38393 \mathrm{e}-06$ & 3,1930 & 0,01275 & $* *$ \\
Gross_enrolment & 65,7287 & 24,6692 & 2,6644 & 0,02861 & $* *$ \\
\hline Youth_Literacy & $-5085,78$ & 2758,2 & $-1,8439$ & 0,10243 \\
\hline \hline Mean dependent var & 11699,20 & S.D. dependent var & 2815,500 \\
Sum squared resid & 5697219 & S.E. of regression & 843,8912 \\
R-squared & 0,934663 & Adjusted R-squared & 0,910162 \\
F(3, 8) & 38,14738 & P-value(F) & 0,000044 \\
Log-likelihood & $-95,45075$ & Akaike criterion & 198,9015 \\
Schwarz criterion & 200,8411 & Hannan-Quinn & 198,1834 \\
Rho & $-0,108248$ & Durbin-Watson & 1,919524 \\
\hline
\end{tabular}

The results show that during the period 2003-2014, it is noted a positive correlation between productivity and Ge or Ee with the regression equation:

Productivity $=\beta_{1}+2,03837 \mathrm{e}-05 \beta_{2}+65,7287 \beta_{3}-5085,78 \beta 4$

With $\mathrm{R}^{2}=0.93$ and adjusted $\mathrm{R}^{2}=0.91$. The results of this correlation are surprising for two reasons. Firstly it is expected that education expenditures have a positive and significant result in productivity while in our model Ee coefficient is almost zero. Secondly, Y1 has an impact on productivity but the relation between them is negative. However, the standard error is very high. This result may be due to the fact that the data for this indicator were limited and we had to calculate some of them based on averages. Regarding the model, it can be said 
that the results are credible because we have a high $\mathrm{R}^{2}$, Durbin-Watson values is greater than one, while p-value is very low. To assess the importance of the model other tests are necessary, ranging from white test for heteroskedasticity, since $\mathrm{R}^{2}$ is high and this test proved to have no heteroskedasticity. In addition to the importance of the model we also consider the criterion $\mathrm{t}$ (student) with reliability coefficient $\alpha=0.05$ and it turned out that $\mathrm{t}$ observed $=$ 9.813309, $\mathrm{t}$ observed $>\mathrm{t}$ critical which shows that the coefficients are important and that Gross_enrolment $(\mathrm{Ge})$ are important for the growth of productivity.

To reinforce the above results and to see that even in the future the expenditures of human capital education has a positive impact on the growth of productivity and GDP in the following it is presented quintile evaluation which is a regression model that serves for the prediction.

Table 2, Model 2, Quintile Evaluation using observations, 2003-2014 $(T=12)$, Dependent variable: Productivity, $\tau=0.5$, Std. Error asymptotic of remnant hypothesis residual IID

\begin{tabular}{|c|c|c|c|c|c|}
\hline & Coefficient & Std. Error & $t$-ratio & $p$-value & \\
\hline const & 464327 & 284670 & 1,6311 & 0,14151 & \\
\hline Education_Expen & $2,07192 \mathrm{e}-05$ & $6,62018 \mathrm{e}-06$ & 3,1297 & 0,01402 & $* *$ \\
\hline Gross_enrolment & 69,4416 & 25,5821 & 2,7145 & 0,02647 & $* *$ \\
\hline Youth_Literacy & $-4670,43$ & 2860,27 & $-1,6329$ & 0,14114 & \\
\hline Mean dependent var & \multicolumn{2}{|c|}{13029,87} & S.D. dependent var & \multicolumn{2}{|r|}{2815,500} \\
\hline Sum squared resid & \multicolumn{2}{|c|}{6090,770} & S.E. of regression & \multicolumn{2}{|r|}{6060664} \\
\hline Log-likelihood & \multicolumn{2}{|c|}{$-95,07324$} & Akaike criterion & \multicolumn{2}{|r|}{198,1465} \\
\hline Schwarz criterion & \multicolumn{2}{|c|}{200,0861} & Hannan-Quinn & \multicolumn{2}{|r|}{197,4284} \\
\hline
\end{tabular}

It results that even in for the future the expenditures of education might have a positive impact on the growth of productivity; while gross enrollment has a tremendous impact on productivity. Like the first model, the second model is also reliable.

Although the above models have limits as the number of observations is only 12 it can be said, however, that human capital has a major role in increasing productivity and as a consequence, in the economic development of a country. Also the increase of spending by the government in the formation of human capital and their education has a primary role in productivity and GDP growth.

\section{Trade Openness- Human Development Index relationship in Albania}

New models of growth connect competitiveness of an economy to its ability to generate innovation and increase productivity through human capital. Lucas (1988) considers human capital as the engine of economic growth. According him different growth rates between countries are not necessarily connected to the level of incomes. Instead of this he argues that:

In the equilibrium of the model, production patterns are dictated by comparative advantage: 


\section{Macrothink}

International Journal of Human Resource Studies

ISSN 2162-3058 2016, Vol. 6, No. 1

Each country produces goods for which its human capital endowment suits it. Given a learning technology like, countries accumulate skills by doing what they are already good at doing, intensifying whatever comparative advantage they begin with. (Page 33)

Another way human capital is thought to serve to economic growth is through the ability to absorb more foreign investments, which is also considered as positively and significantly correlated to the economic growth of a country. Some authors suggest that FDI flow require the existence of a minimum stock of human capital because human capital determines the host country's absorptive capability (Borensztein et al., 1995).

But according to Krugman $(1985,1998)$ among endogenous and exogenous factors that lead a company to internationalize the production is productivity and scalar efficiency that depend on the development of human capital and above all specialization. Foreign investments in their turn influence more positively to the economic development of a country as well as they help in increasing productivity, economic growth, the transfer of technology and above all in an improvement of managerial and know-how competencies (Grotte (1966) and Borensztein et al. (1998)). Lee (2002) adds that the growth of foreign investments later leads to increased competitiveness and exports. For this reason we consider the relation between human development index HDI, and indicator of trade openness, trade volume/GDP.

Table 3, Model 3, OLS, using observations 2005-2013 ( $\mathrm{T}=9$ ), Dependent variable: HDI

\begin{tabular}{|c|c|c|c|c|c|c|}
\hline & Coefficient & \multicolumn{2}{|c|}{ Std. Error } & t-ratio & \multicolumn{2}{|l|}{$p$-value } \\
\hline const & 0.632226 & \multicolumn{2}{|c|}{0.00808055} & 78.2404 & $<0.00001$ & $* * *$ \\
\hline TrVol_GDP & 0.144179 & \multicolumn{2}{|c|}{0.0159728} & 9.0265 & 0.00004 & $* * *$ \\
\hline Mean dependent var & \multicolumn{2}{|c|}{0.704667} & \multicolumn{2}{|c|}{ S.D. dependent var } & \multicolumn{2}{|c|}{0.009407} \\
\hline Sum squared resid & \multicolumn{2}{|c|}{0.000056} & \multicolumn{2}{|c|}{ S.E. of regression } & \multicolumn{2}{|c|}{0.002829} \\
\hline R-squared & \multicolumn{2}{|c|}{0.920884} & \multicolumn{2}{|c|}{ Adjusted R-squared } & \multicolumn{2}{|c|}{0.909582} \\
\hline $\mathrm{F}(1,7)$ & \multicolumn{2}{|c|}{81.47823} & \multicolumn{2}{|c|}{ P-value $(F)$} & \multicolumn{2}{|c|}{0.000042} \\
\hline Log-likelihood & \multicolumn{2}{|c|}{41.17167} & \multicolumn{2}{|c|}{ Akaike criterion } & \multicolumn{2}{|c|}{-78.34334} \\
\hline Schwarz criterion & \multicolumn{2}{|c|}{-77.94889} & \multicolumn{2}{|c|}{ Hannan-Quinn } & \multicolumn{2}{|c|}{-79.19456} \\
\hline rho & \multicolumn{2}{|c|}{-0.067590} & \multicolumn{2}{|c|}{ Durbin-Watson } & \multicolumn{2}{|c|}{2.098804} \\
\hline
\end{tabular}




\section{MInstitute Macrothink $_{\text {Int }}$}

International Journal of Human Resource Studies

ISSN 2162-3058

The results above show that during the period 2005-2013 a positive correlation between HDI and trade openness indicator is observed. This model looks relatively stable taking into account the fact that $R^{2}=0.92$ and adjusted $R^{2}=0.90$. Standard error is very low; Durbin-Watson also is greater than one, while p-value is very low. This model supports in the case of Albania, like what in most of the international literature states: that that human capital remains a key factor through which a country can best take advantage of foreign direct investments and develop economically.

\section{Conclusions}

From literature review and empirical analysis it was confirmed once again the primary role that human capital has for a country's economic development. It was also observed that public spending and education have a moderate role in increasing productivity which is often synonymous with increased competitiveness and development.

Considering what Schumpeter says that: the university transforms the theoretical knowledge in added value, for an enterprise it is very important to find the instruments of economic policy, and labor policies in order to guide the university and government bodies to be engaged even more in education promotion, to increase its quality both in the pre-university and the university levels, enabling thus the preparation of a qualified human capital that will serve later for attracting serious foreign investments that also need highly qualified staff, paid with high salaries which would tend to increase consumption and as a result will increase the aggregate demand. It is also necessary to create a partnership between businesses that operate in a certain territory with universities both public and private, to create university courses that help to learn or to meet in an optimal way the requirements of companies and also to make easier the employment of new graduates.

In Albania, like in any other country, the success of education system in developing higher levels of knowledge or skills acquired will be an important determinant of future economic development of the nation. Not forgetting the fact that the major part of the workforce in Albania is concentrated in small and medium enterprises, SME, the need for entrepreneurial skills and knowledge is essential. Under these circumstances, emphasis should be placed on an education system education which prepares graduates with these skills. This from the other part would ensure easier employment and higher welfare. Finally it is important for government policies regarding education, to change toward education quality improvement more than toward the number of students that pass through the system in the short term.

\section{References}

Barrett, A., O'Connell, P. J., 2001, Does training generally work? The returns to in-company training. Industrial \& labor relations review, 54(3), 647-662

Barro, R., 1991, Economic Growth in a Cross Section of Countries. Quarterly Journal of Economics, Vol.106, No.2, pp.407-443.

Barro, R. J., Xavier Sala-I-Martin, 1995, Economic Growth. New York: McGraw-Hill, Inc.

Bils, M., Klenow, P. J., 2000, Does Schooling Cause Growth? The American Economic 
Review, Vol. 90 No. 5:1160- 1183.

Borensztein, E.; de Gregorio, J., Jong-Wha, L., 1995, How does Foreign Direct Investment Affect Economic Growth? NBER Working Paper 5057.

Chen, D. H. C., Dahlman, C. J., 2004, Knowledge and Development A Cross-Section Approach. World Bank Policy Research Working Paper 3366.

Christoforou, A., 2003, Social Capital and Economic Growth: The Case of Greece. European Institute, London School of Economics.

De la Fuente, A., Ciccone, A. 2003, Human capital in a global and knowledge-based economy. Universitat Autònoma de Barcelona, Departament d'Economia i d'Història Econòmica, Unitat Fonaments de l'Anàlisi Econòmica

Fullani, A., 2012, Growth in Albania and South East Europe: The Way Ahead. South East European Studies at Oxford (SEESOX), European Studies Centre St Antony's College University of Oxford.

Hanushek, E., Kimko, D., 2000, Schooling, Labor-Force Quality, and the Growth of Nations. The American Economic Review Vol. 90, No 5: 1184-1208.

Hanushek, A. E., 2002, The Long Run Importance of School Quality. NBER Working Paper Series, Working Paper 9071.

Hanushek, A. E., Wößmann, L., 2007, The Role of Education Quality in Economic Growth. World Bank Policy Research Working Paper 4122.

Hanushek, E., 2013, Economic Growth in Developing Countries: The Role of Human Capital. Stanford University.

Hoti, A., 2004, Human Capital and Unemployment in Transition Economies: The Case of Kosova. Pages 163-183

Human Development Report 2014. Sustaining Human Progress: Reducing Vulnerabilities and Building Resilience. UNDP.

Isola, W. A., Alani. R. A., 2012, Human capital development and economic growth: Empirical evidence from Nigeria. Asian Economic and Financial Review 2(7):813-827.

Lucas, E.R., 1988, On the Mechanics of Economic Development. Journal of Monetary Economics, 3-42. North-Holland.

Mehrara, M., Musai, M., 2013, The relationship between Economic Growth and Human Capital in Developing Countries. International Letters of Social and Humanistic Sciences Vol. 5 (2013) pp 55-62.

Micklewright, J., 2000, Education, Inequality and Transition. Economic and Social Policy Series no.74.

Mincer, J., 1981, Human Capital and Economic Growth. National Bureau of Economic 


\section{Macrothink \\ International Journal of Human Resource Studies \\ ISSN 2162-3058 2016, Vol. 6, No. 1}

Research, Working Paper No. 803.

OECD 1998. Human Capital Investment: An International Comparison. Centre for Educational Research and Innovation.

Pritchett, L, 2001, Where has all the education gone? World Bank Economic Review 15, no.3:367-391.

Spencer, L. M., Spencer, S. M., 1995, Competenza nel lavoro: modelli per una performance superiore (Vol. 2). Franco Angeli

Schütt, F., 2003, The Importance of Human Capital for Economic Growth. Institute for World Economics and International Management.

Vinod, D. H., Kaushik, K. S., 2007, Human capital and economic growth: Evidence from developing countries. The American economist Journal of the International Honor Society in Economics.

Wilson, A. R., Briscoe, G., 2004, The impact of human capital on economic growth: A review. Third report on vocational training research in Europe: background report. Luxembourg: Office for Official Publications of the European Communities.

Zwick, T., 2002, Continuous training and firm productivity in Germany ZEW Discussion Papers (No. 02-50). 